\title{
Conservation of Genetic Diversity of Tomatoes (Lycopersicon esculentum Mill.)
}

\author{
Cristian ALBU ${ }^{1}$, Aurel MAXIM1 ${ }^{*}$, Raluca-Maria PÂRLICI ${ }^{1}$ \\ ${ }^{1}$ Department of Engineering and Environmental Protection, Faculty of Agriculture, University of Agricultural Sciences \\ and Veterinary Medicine, Cluj-Napoca, 400372, Romania \\ * Corresponding author: A. Maxim e-mail: aurel.maxim@usamvcluj.ro
}

RESEARCH ARTICLE

\begin{abstract}
Among the main problems encountered with crop plants, the most important one is represented by genetic erosion. At world level this issue has been debated within the Convention on Biodiversity adopted in UN Conference of Rio de Janeiro and The International Convention regarding Genetic Resources of Plants for Alimentation and Agriculture. In Europe, the regulations in this field are made by the European Directive 98/95 EEC. Across time tomatoes have suffered a heightened process of genetic diversity, phenomenon caused by industrialized farming which is based on the use of very uniform varieties with high productivity. The extension of green agriculture, has led to the use of landraces, because they respond best to the traditional farming systems. In Western Europe organizations of peasants had been founded and, they are involved in different activities aiming at conservation of traditional forms of agriculture and the use of old varieties. In Romania the institutions with continuous preoccupations in the field of vegetal genetic conservation, especially landraces, are the Gene Bank from Suceava and UASMV Cluj-Napoca. By using conservation methods (in situ and ex situ), the genetic erosion surely phenomenon of vegetal genetic resources, implicitly tomatoes, is reduced, the future generations will benefit from valuable genetic resources.
\end{abstract}

Keywords: agrobiodiversity, conservation, genetic erosion, landraces, tomatoes.

Received: 03 February 2021

Accepted: 08 May 2021

Published: 15 May 2021

DOI:

10.15835/buasvmcn-agr:2021.0001

\section{INTRODUCTION}

Among the main problems encountered with the crop plants, the most important one is represented by genetic erosion, defined as "loss over time of genetic diversity between populations or varieties from the same species or reduction of genetic basis of a species due to human intervention or climate changes" according to Directive 2008/62/EC. This topical issue has led to the need to protect the vegetal genetic resources, protection stimulated by Conventions (at world level) and directives (at European level). At world level, this issue has been debated in the Convention on Biodiversity adopted at the UN Conference of Rio de Janeiro (1992) and at The International Convention regarding Genetic Resources of Plants for Alimentation and Agriculture (2001). At European level, the regulations in this field are made by the European Directive 98/95 EEC but also by other directives (Zaharia, 2003; Maxim, 2008).

Across time tomatoes have suffered a strong reduction of genetic diversity and this increasing trend is known as genetic erosion. Human intervention on the intensification of genetic erosion is high and has severe implications on the future programmes for biodiversity management and use (Kulus, 2018).

Industrialized agriculture uses varieties with high uniformity, and this practice entails also a high vulnerability for the varieties used. In order to reduce as much as possible, the risk of failure in crop, we recommend the use of as many assortments and varieties as possible. The local varieties have frequently genes 
which confer them resistance to diseases, pests, drought and even other biotic and abiotic stress factors. By the appearance of green revolution in 1960', the farmers all over the world started to practise modern agriculture (by using modern varieties with high uniformity) and to abandon the traditional agricultural practices (which were based on the use of old varieties, local varieties of plants). Cultivation of modern varieties offered farmers high productions, but also the opportunity to use intensive crop technologies. Industrialized agriculture has led to the loss of many traditional varieties and local varieties of plants used in the traditional agricultural practices. The high productions offered by the modern varieties bring short-term benefits to farmers, but the viability of agriculture depends on the protection of valuable genes offered by the local varieties (Cleveland et. al., 1994; Villa, 2005; Maxim et. al., 2008).

The extension of green agriculture in recent years associated with the preferences of consumers for green products has led to the use by farmers of landraces and old varieties, because they respond best to the farming systems with reduced inputs (Maxim et. al., 2008; Chable, 2005; Micheloni, 2004, Lammerts van Bueren at. al, 2002).

In Western Europe, there are many peasant organizations which are involved in activities for preservation of traditional forms of agriculture and use of old varieties of crop plants. Among the most important peasant organizations there are: Semences paysannes, Nature at Progres, Confederation paysanne, Les Semences de Kokopelli etc. (Maxim et. al., 2008).

In Romania, the institutions with continuous preoccupations in the field of vegetal genetic conservation of crop plants, especially landraces, are represented by the Gene Bank from Suceava and the University of Agricultural Sciences and Veterinary Medicine (USAMV) Cluj-Napoca. The two institutions carry out actions for identification of the seeds manufacturers, and after their collection, they were studied in experimental fields, but also in laboratory (Străjeru, 2006; Maxim et. al., 2007; Maxim et. al., 2008).

The main objectives of this work are highlighting the importance of vegetal genetic resources conservation, situation that exists at world level and in Romania, such as the description of conservation methods used at world, European and national level.

The sources of information underlying this work were the scientific research (specialised publications, books, etc), but also the databases and publications of FAO and EUROSTAT.

\section{EVOLUTION OF TOMATO CROP AT WORLD LEVEL AND IN ROMANIA}

The first crops of tomatoes in Europe were in Spain and Portugal, in the $18^{\text {th }}$ Century, from where they started to extend to Italy. At the end of $18^{\text {th }}$ Century, the tomatoes have spread to Western European countries and in the remaining European countries in the beginning of $19^{\text {th }}$ Century (Ciofu et al., 2004).

In Romania, the tomato crop started to grow at the end of $19^{\text {th }}$ Century and the beginning of $20^{\text {th }}$ Century in the Romanian Principalities, with the introduction of the production method of nursery transplants in hotbeds, borrowed from the Bulgarian and Serbian neighbours.

Romania records a growth of surface cultivated with tomatoes during 1938-1980, by nine times, which means from an area of 8.4 thousand hectares to 74.6 thousand hectares, it recorded an average production of $6.25 \mathrm{t} / \mathrm{ha}$ in 1938 , and an average production of $13.88 \mathrm{t} / \mathrm{ha}$ in 1980. After 1980, the areas cultivated with tomatoes recorded a continuous decrease thus, in 1989 the cultivated surface was 52 thousand ha, but with an average production of $15.6 \mathrm{t} / \mathrm{ha}$, which was higher than in 1980 (Stan et al., 2003).

\section{IMPORTANCE OF LOCAL VARIETIES OF TOMATOES}

Tomatoes (Lycopersicon esculentum Mill.) range among the most important vegetal crops in worldwide from economic perspective. The fruits of tomatoes are among the most used vegetables, both in fresh state (for salads), but also in cooked and processed forms such as mash, paste, ketchup, etc (Izahur, et al., 2018). Along with other nutrients, tomatoes contain $\beta$-carotene, vitamin C and B1, B2, B3, folic acid, nicotinic acid, provitamin A, potassium salts, sodium, magnesium, iron, iodine, phosphorus, phenolic compounds, which offer plenty of benefits for the health of consumers. Lycopene, a major antioxidant, with well-known role in the prevention and even the treatment of many diseases of human body is also found in tomato fruits (Krasteva L., and Todorova T., 2003; Martí, 2016).

According to a study carried out by Spanish scientists, organic tomatoes have a higher level of antioxidants than the one of vegetables cultivated traditionally. In organic agriculture, the chemical fertilizers based on nitrogen are not allowed, the plants which are thus grown activate their own defence mechanisms against pests and this process favours the growth of antioxidant level (Vallverdú - Queralt Anna et. al., 2011).

During 2017-2018, at world level, tomatoes were cultivated on an area of 11.68 million hectares, with a production of 484.433 million tonnes (Chart 1) - FAOSTAT 2019.

At European Union level, according to EUROSTAT 2020, the surface cultivated with vegetables in 2017 was 2,231.23 million ha and in 2018 a surface of 2,218.01 million ha was cultivated.

According to the statistics of the European Commission (EC), in 2020, the production of tomatoes at European Union level (EU) expressed in tonnes ranks Romania on the sixth position with a total production of 426.5 thousand tonnes in 2019. Compared to 2018, when Romania recorded a production of 464.0 thousand tonnes, in 2019 it 
recorded a decrease of production by $8 \%$. In this vegetable species, on the first three positions are ranked Italy (top position) with a production of 5,252.7 thousand tonnes, followed by Spain with a production of 5,000.6 thousand tonnes and by Greece with a production of 827.9 thousand tonnes (2019).

As for the processing of tomatoes (for sauces, juice, ketchup, etc.) out of total production in 2019, Italy processed a quantity of 4,729.0 thousand tonnes, Spain 3,138.7 thousand tonnes, and Greece 303.6 thousand tonnes. For the year 2019 EC statistics did not provide data regarding the quantity of tomatoes processed by Romania.

From the perspective of quantity of tomatoes used for consumption in fresh state, Romania is ranked on the sixth position, in EU, with a total consumption of 426.5 thousand tonnes (2019). Just as in productions, the first three positions of classification are filled by Italy with a consumption of 523.7 thousand tonnes, followed by Spain with 1,861.9 thousand tonnes, and then by Greece with a consumption of 523.4 thousand tonnes (https://ec.europa.eu/info/sites/info/files/food-farming-fisheries/farming/documents/tomatoes-production en.pdf.).

\section{Tomato yields, 2018 \\ Yields are measured in tonnes per hectare.}
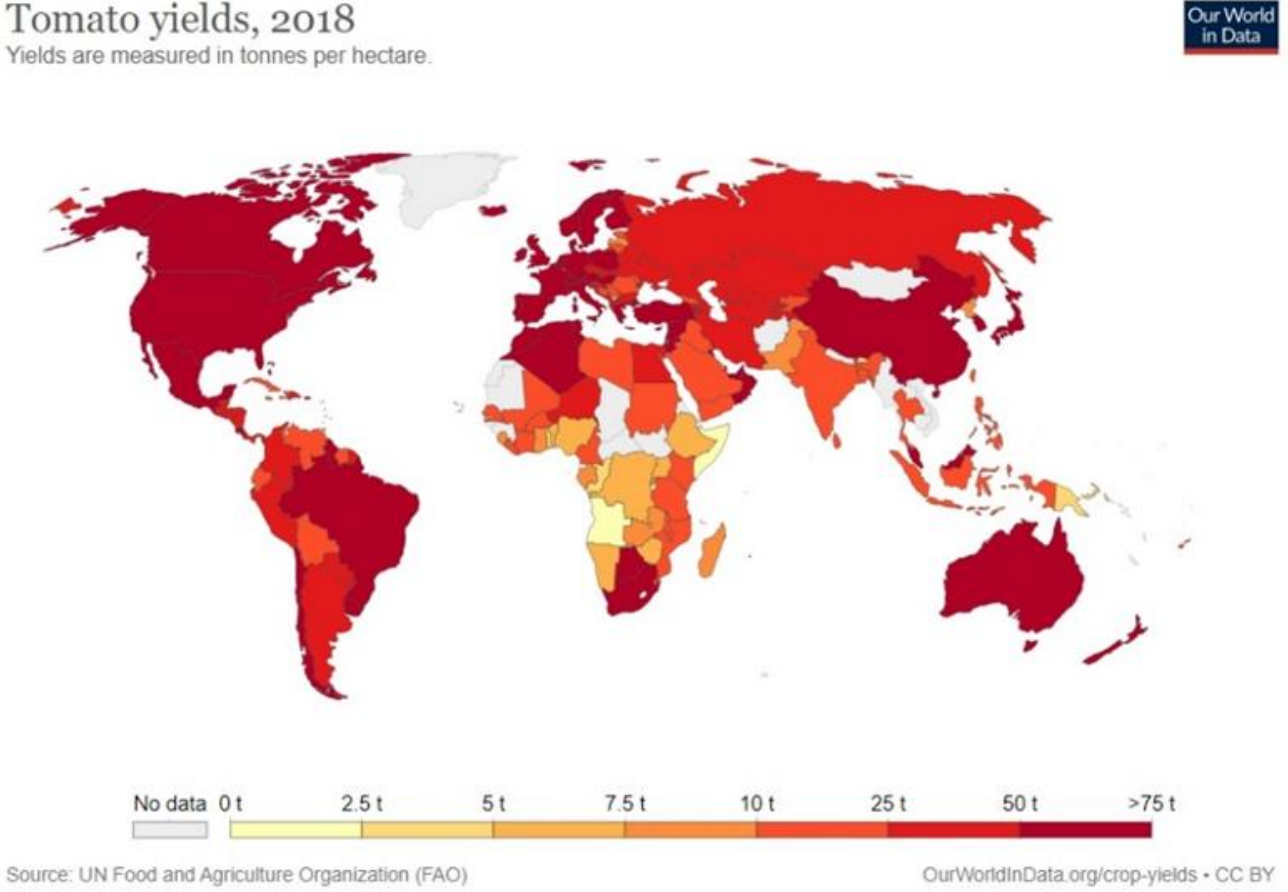

Figure 1. Production of tomatoes at world level in 2018, expressed in tonnes/hectare (https://ourworldindata.org/grapher/tomato-yields)

In 2018 the total surface cultivated with tomatoes in Romania was 40.7 thousand hectares, recording a total yield of 742.8 thousand tonnes (table 1) and an average yield of $18235 \mathrm{~kg} /$ hectare - Chart 2 - (INS - Vegetal production of the main crops, 2019).

Table 1. Surfaces and production of tomato crop in Romania during the years 2017 - 2018 (INS - Vegetal production of the main crops, 2019)

\begin{tabular}{|c|c|c|c|c|}
\hline Crop & Specification & M.U. & $\mathbf{2 0 1 7}$ & $\mathbf{2 0 1 8}$ \\
\hline \multirow{2}{*}{ Tomatoes } & Area & Thousand hectares & 40.0 & 40.7 \\
\cline { 2 - 5 } & Total production & Thousand tonnes & 679.8 & 742.8 \\
\hline \multicolumn{2}{|c|}{$\begin{array}{c}\text { Total surface cultivated with } \\
\text { vegetables }\end{array}$} & Thousand hectares & 226.2 & 3797.4 \\
\hline \multicolumn{2}{c}{$\begin{array}{c}\text { Total production of vegetables } \\
\text { cultivated* }\end{array}$} & Thousand tonnes & 3638.4 & 18.235 \\
\hline \multicolumn{2}{|c|}{ Average yield per hectares } & Kilogram per hectare & 16.978 & \\
\hline
\end{tabular}

*including the production from family gardens, hothouses, solariums, successive and interpolated crops

As shown in the table above, the surface cultivated with tomatoes in 2018 recorded a slight increase compared to the year 2017, respectively by +0.7 thousand hectares.

Compared to the year 2017 when a production of 679.8 thousand tonnes of tomatoes was recorded, the year 2018 recorded an increase by +63.1 thousand tonnes and a yield of 742.8 thousand tonnes.

Average tomato yield per hectare recorded an increase in 2018 by $6.9 \%$ compared to the year 2017 . 


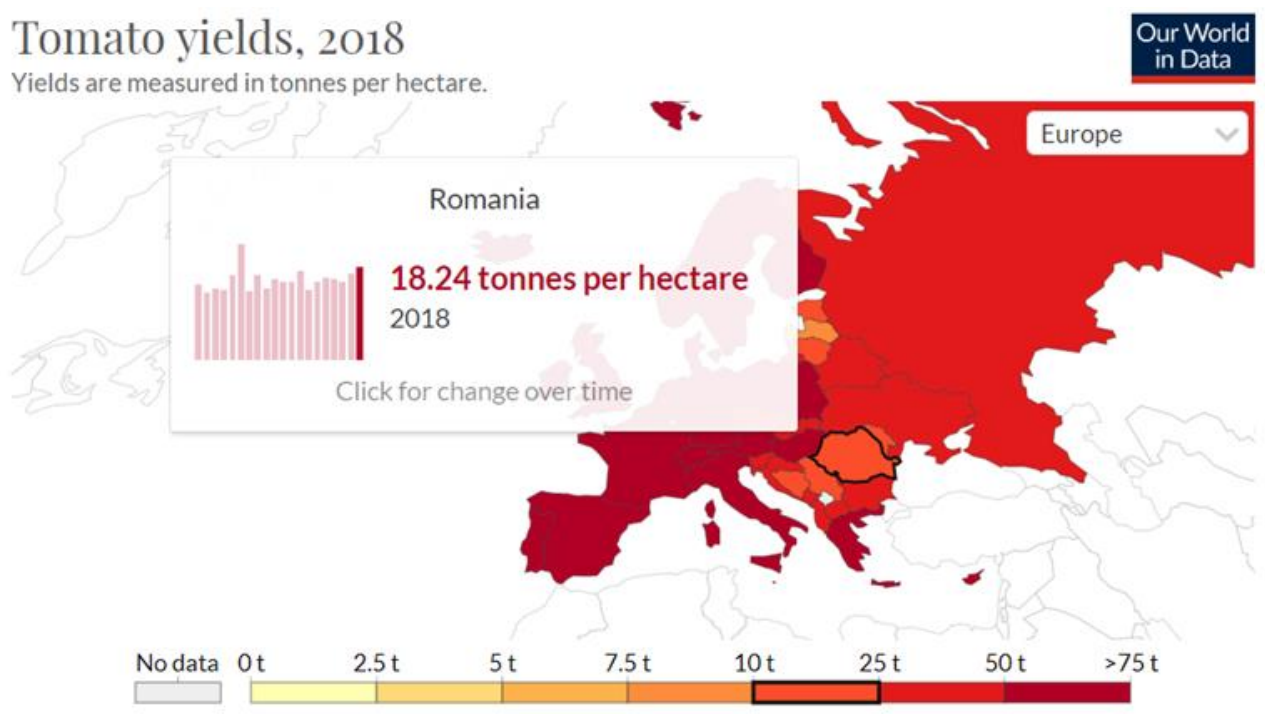

Source: UN Food and Agriculture Organization (FAO)

OurWorldlnData.org/crop-yields • CC BY

Figure 2. Tomato yield in Romania for the year 2018, expressed in tonnes/hectare (https://ourworldindata.org/grapher/tomato-yields?time=2018\&country= $\sim$ ROU\&region=Europe)

According to the temporary data of General Agricultural Census (GAC) from 2010, out of the total surface of Romania (23.8 million hectares), the surface of exploited land is 13.3 million hectares, and from this surface, the arable land represents 8.3 million hectares. By the method of use, arable land occupies $62.5 \%$ of total agricultural area.

\section{CONSERVATION OF GENETIC RESOURCES IN TOMATOES}

In each local variety there are many genotypes in continuous evolution, due to the natural or artificial selection pressure. For local varieties, the selection does not lead to the genetic uniformity of modern varieties. The genetic diversity in the local populations responds to the various needs and purposes of farmers. Regardless of the biotic or abiotic stress (drought, high humidity, attack by diseases and pests, etc.) to which the crop is exposed, there will be genotypes which will resist (Jarvis, et al., 2008).

As the definition suggests, the local varieties (landraces) are characterised by a high heterogeneity. Landraces have the advantage that they are better adapted to the biotic and abiotic stress conditions (diseases, pests, drought, poor in nutrients etc.) and have excellent gustative qualities, which can justify the higher selling prices compared to the commercial landraces (Stickland, 1998).

Landraces represent a priceless genetic potential in order to obtain new varieties of plants and are the most suitable for the cultivation of crops in green systems, which have become more frequent (Negri et. al., 2009). Also, for the long-term food security in the context of global warming, a rich genetic diversity will be necessary (Tsegaye, et. al., 2007). These varieties can occupy a certain market niche which generates significant income for the rural population, by keeping the genetic diversity "in the farm".

Having these features, the tomato crops from landraces have low inputs, therefore, they correspond to the sustainable development concept. The high demand of products obtained from conventional farming systems, has led to a significant economic potential for landraces, suitable for green systems of crops.

FAO recommends the cultivation of varieties which use productively the resources of water and nutrients and which have (genetic) resistance to the attack of parasites and even heat (Derpsch et al., 1991; Bertoldo et al., 2014).

In Romania, the Gene Bank from Suceava has in patrimony a number of 406 samples of tomato landraces from the genus Solanum lycopersicon L. (Stăjeru, 2018).

The conservation of vegetal genetic resources of tomatoes (in situ and ex situ) refers to all the human activities, strategies, plans, policies and actions designed to assure the maintenance of genetic diversity of plants both for the current and future production of food, but also for their ecological and cultural values.

The conservation initiatives discover the old local varieties, use them and then promote their features and diversity. The two great strategies in situ and ex situ are used for conservation of genetic resources of plants. Between the two strategies there is a basic difference: by conservation ex situ we collect samples, transfer and cultivate in other places than the original ones, while the conservation in situ (on the farm) involves the identification of authentic local varieties, their management and monitoring in the place of origin (Negri et. al., 2009; Veteläinen et. al., 2009). 
The Convention for Biological Diversity - 1992, mentions that the two strategies must not be regarded as alternatives or in opposition, on the contrary they must be treated complementarily. The conservation in situ of vegetal genetic resources can be made only by continuing the cultivation of local varieties in the areas of origin and by original production systems (Stickland, 1998).

\section{Conservation ex situ of genetic resources of tomatoes}

Conservation ex situ is made in banks of genes (banks of seeds), work collections, biostocks, etc. The activity of gene banks involves the collection of seeds from various local varieties of crop plants and their storage in sealed spaces (frigorific chambers), in controlled environment (temperature, humidity, light etc.) to inhibit their germination for a certain period of time. The conservation method of seeds in gene banks is considered essential for protection of vegetal genetic resources, but also has certain disadvantages such as: gradual loss of germinative capacity of seeds, the appearance of harmful mutations, refreshing of stocks of seeds after a certain period, etc.

For a local variety to be accepted in the gene bank, it has to be accompanied by passport descriptors issued by the International Institute for Vegetal Genetic Resources (IPGRI) which allow for identification of samples, but also the exchange of information at regional, national and even world level. Each assortment or local variety introduced in the gene bank must be accompanied by a primary or secondary characterization. The characterization involves the morphological and agronomic description, and the secondary evaluation refers to agronomic, cytological and molecular characterization. In secondary evaluation stage, the evaluation descriptors, unlike the characterization descriptors, refer to the characters which are susceptible to environmental factors, but are important for the improvement of plants (Străjeru et. al. 2006).

Nowadays, there are about 1,750 gene banks at world level, which hold about 7.4 million species of germ-plasma. Out of total, only 130 hold over 10,000 species each. Conservative Group on International Agricultural Research (CGIAR) holds 11 centres, which preserve about $10 \%$ of total number of adhesions, but represent about $94 \%$ of germ plasma distributed according to the guidelines of the International Treaty for Phytogenetic Resources for Food and Agriculture (The Second Report on the State of the World's 2010).

Figure 3 offers a clear image of the geographic distribution of gene banks which hold more than 10,000 species at world level.

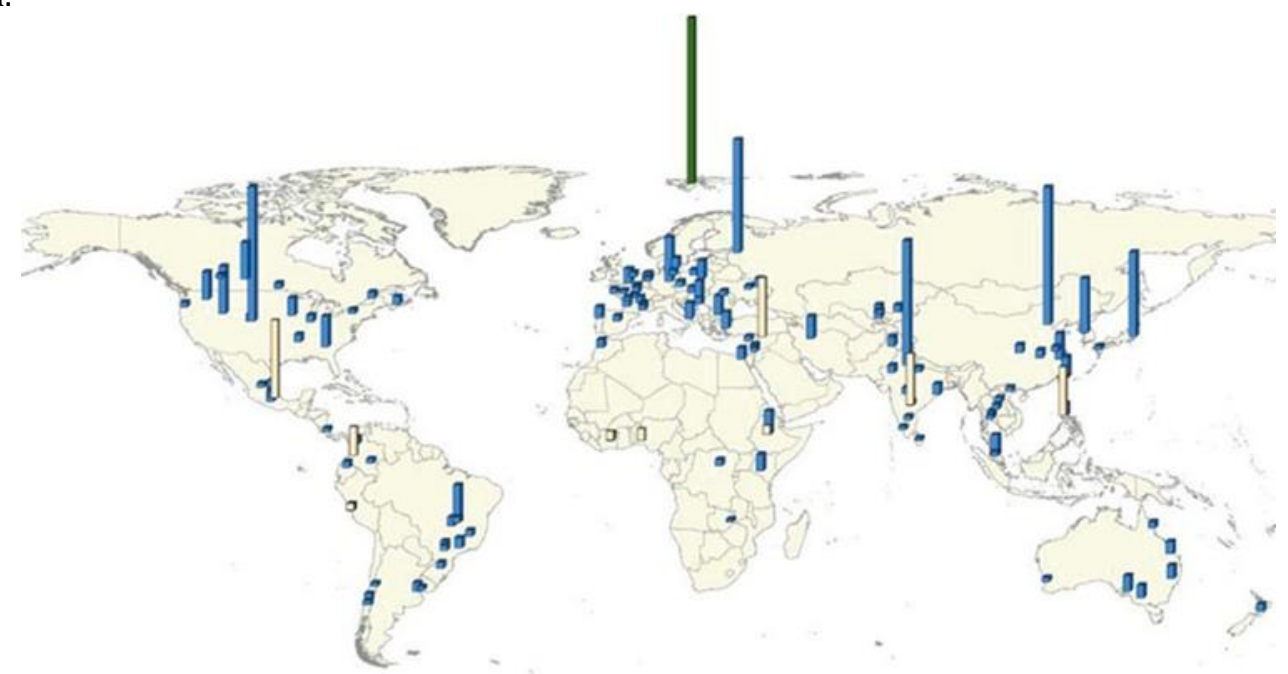

Figure 3. Geographic distribution of gene banks which hold more than 10,000 species. National and regional gene banks - blue; CGIAR- beige; Svalbard Global Seed Vault (SGSV) - green (The Second Report on the State of the World's 2010)

The beginning of 1980's represented the alarm signal at world level regarding the loss of genetic diversity, especially in the traditional varieties of crop plants (Fowler and Pat, 1990).

At world level, the cultivation of tomato landraces is carried out in poorer regions, where the local population still holds old vegetal genetic resources and practises the family farming. Kennet et. al, in 2018 studied a number of 69 tomato landraces obtained from the World Vegetable Center and the National Genetic Resources in Kenya. Out of total 69 landraces studied, they come from countries such as Ethiopia (16), Morocco (15), Madagascar (14), South Africa (10), Egypt (3), Mauritius (3), Kenya (2), Tanzania (2), Zimbabwe (2), Nigeria (1) and Zambia (1). The result of research highlighted the richness of genetic diversity of tomato landraces studied.

Another region with a high number of tomato landraces, more exactly 96, is Tanzania (South Africa) and those landraces are identified in seven regions of the country. All the landraces identified and studied were preserved in the Gene Bank from Tanzania. Half of tomato landraces were identified in the households of local inhabitants (54\%), followed by the area of agricultural land associated with annual and perennial crops $(40 \%)$, and about $6 \%$ were identified in abandoned fields (William, et. al. 2016). 
In the 2000's at European level was generated a virtual database A European Genebank Integrated System (AEGIS) which includes unique and important species of all vegetal genetic resources for food and agriculture conserved in Europe (Johannes and Lorenzo, 2018).

In Europe, a regional network was founded, called European Cooperative Programme for Plant Genetic Resource (ECPGR), which is focused on collection, conservation, characterization and evaluation of relevant crops for Europe (https://www.ecpgr.cgiar.org/).

At the beginning of 2000's ECPGR started to establish a European integrated system of gene banks, which has as main objective, "the conservation in collaboration and in line with the quality standards, unique and important genetic adhesion for Europe of all crops and making them available for reproduction and research". It is worth mentioning the collaboration of ECPGR with Svalbard Global Seed Valut (SGV) for the use of a warehouse SGV as a possible option for assuring the safety doubling requirements AEGIS.

Out of 1,750 gene banks that exist at world level, a number of 625 (35.71\%) exist in Europe, and out of total 7.4 million species of germ-plasma, about 2.0 million (27.02\%) are in Europe (Johannes and Lorenzo, 2018).

Romania has a remarkable agrobiodiversity; the vegetal sector is the most representative one by holding genetic resources of all categories. In Romania, according to the data published in 2018 by the Gene Bank from Suceava (BGS), its patrimony is represented by a number of 428 species of plants, which represent about 18,000 different varieties. Out of total samples held by BGS, tomato landraces are represented by a number of 406 samples, mostly from Romania, but also other countries such as Hungary, Bulgaria and Italy (Străjeru, 2018).

At the USAMV Cluj-Napoca, since 2007 until now a number of 51 tomato landraces were studied and characterized, were investigated in experimental fields for the identification of authentic landraces. In 2017, the State Institute for Testing and Registration of Varieties (ISTIS) approved two varieties of tomatoes, among the most valuable landraces studied, Cassiana and Danamari. The variety Cassiana comes from Marin village, Sălaj county, while Danamari has its origin in the town Sebeș, Alba county. Both varieties are suitable for cultivation in hothouse or cultivation in the field. Apart from their special organoleptic qualities, the two varieties stand out by high resistance to mildew (Phytophtora infestans (Mont.) de Bary), which makes them suitable for crop ecological system.

\section{Conservation in situ of tomato genetic resources}

Maxted et. al (1997) defined the conservation in situ (on the farm) as "sustainable management of genetic diversity in crop plants developed on local level, associated with the wild species and forms and with the traditional systems of agricultural, horticultural or agro-forestry crop". Conservation in situ must be associated with the traditional crop technologies, without using the modern technologies and equipment.

Conservation on farm of vegetal genetic resources can be made by continuing the cultivation of assortments and local varieties, by their holders, in the areas of origin and in the original crop systems.

Among the main dangers of conservation in situ, there are: replacement of traditional assortments and local varieties with hybrids and/or performed assortments with high yield, the aging of population who uses the old assortments in the crop systems, transformation of old farms in holiday houses (Lever, 2006; Maxim et. al., 2007; Nikolaou and Maxted, 2009).

The Agroecosystem by its stability can offer benefits to society by low use of chemical substances in agriculture, by promotion of old assortments and local varieties of plants. For farmers, the conservation on farm could support the cultural traditions, would reduce the budgetary constraints, would mitigate the attack of diseases and pests and even other types of biotic and abiotic stress factors. A part of the possible advantages due to conservation on farm are presented in table 2 below (Jarvis et. al., 2000).

Table 2. Possible advantages of on farm conservation (Jarvis et. al., 2000)

\begin{tabular}{|c|c|c|c|}
\hline $\begin{array}{c}\text { Household } \\
\text { of farmer }\end{array}$ & $\begin{array}{c}\text { Economic and sociocultural } \\
\text { benefits }\end{array}$ & $\begin{array}{c}\text { Environmental } \\
\text { benefits }\end{array}$ & Genetic benefits \\
\hline & $\begin{array}{c}\text { Adjustment of various financial } \\
\text { uncertainty } \\
\text { constraints } \\
\text { Minimization and avoidance of } \\
\text { workforce blockages. } \\
\text { Continuity of certain rituals and } \\
\text { creation of social connections. } \\
\text { Fulfilment of nutritional needs }\end{array}$ & $\begin{array}{c}\text { Improvement of soil } \\
\text { structure } \\
\text { Resistance to diseases } \\
\text { and pests }\end{array}$ & $\begin{array}{c}\text { Assurance against } \\
\text { socio-economic and } \\
\text { environmental changes }\end{array}$ \\
\hline & $\begin{array}{c}\text { Global food security } \\
\text { Society }\end{array}$ & $\begin{array}{c}\text { Seduction of chemical } \\
\text { pollution } \\
\text { Restraint of plant } \\
\text { diseases }\end{array}$ & $\begin{array}{c}\text { Assurance against } \\
\text { environmental changes, } \\
\text { diseases and pests. }\end{array}$ \\
\hline
\end{tabular}




\begin{tabular}{|c|c|c|c|}
\hline & $\begin{array}{c}\text { Economic and sociocultural } \\
\text { benefits }\end{array}$ & $\begin{array}{c}\text { Environmental } \\
\text { benefits }\end{array}$ & Genetic benefits \\
\hline & & $\begin{array}{c}\text { Adjustment of hydric } \\
\text { flows }\end{array}$ & $\begin{array}{c}\text { It is for the benefit of } \\
\text { agricultural sector. }\end{array}$ \\
\hline
\end{tabular}

The management and conservation on farm of vegetal genetic resources, but especially the maintenance of crops with traditional assortments in agricultural systems gained impetus. At world level, national and international programmes were founded for promotion of conservation on farm (Sthapit et. al., 2008).

The Second Report on the State of the World's Plant Genetic Resources for Food and Agriculture (PGRFA), published by FAO in 2010, presented the global system of conservation areas on farm by highlighting the conservation priorities.

PGRFA also presented the existence of variations between the production systems and the reports presented by the participating countries, which highlighted that the highest levels of genetic diversity of crops were encountered in areas where the vegetal production is extremely difficult, such as the areas represented by the edges of deserts or areas with high altitudes, where access to resources is more difficult. The information provided in the reports of participating countries was poor in details about the traditional assortments used and maintained in the agricultural crops of farmers.

From the reports of participating countries, it results that in Romania, more exactly in Western Carpathians, over 200 landraces of crop plants were identified (PGRFA).

In addition, in Romania Transylvania represents the region with the highest genetic diversity of vegetables, in the counties Maramureș, Bistrița-Năsăud and Hunedoara. Another region with a significant genetic diversity is represented by Bucovina, region neighbouring Transylvania (Străjeru et. al., 2009).

In Transylvania, tomatoes are ranked on the top position among the most cultivated vegetables. Most tomato landraces identified were in number of 102, found in this region of Romania, which shows the importance of this crop for the farmers in the area. Practically, in this region, tomatoes are present in any vegetable garden. (Maxim et. al., 2020).

It is important to point out that at European level, there are serious concerns regarding the rescue and conservation of landraces. In 2002, Kokopelli Confederation from France published a reference manual The seeds of Kokopelli - A manual for the production of seeds in the family garden. A directory of heritage seeds which presented a number of 2500 assortments and species, among which the tomatoes are represented by a number of 600 assortments. The role of this manual is to provide valuable information about the rescue, cultivation and benefits offered by landraces (tomatoes, carrots, cucumbers, etc), but also the list of organizations of farmers who does with the salvage, cultivation and supply of landrace seeds. The 600 tomato landraces found in the manual stand out by a large diversity of colours, tastes, shapes and also by genetic resistance to biotic and abiotic stress factors. Another noteworthy issue is the description of each assortment of tomato, which allows farmers to pick landraces which are most suitable for the pedoclimatic conditions of the region. The yield of tomato assortment is another characteristic found in the manual, a major criterion which highlights the agronomic value decisive in each crop.

In Romania, a similar activity has been carried out since 2009 by the NGO ECO Ruralis - for the support of peasant agriculture, with office in Cluj-Napoca. The NGO was founded by small farmers from different regions of Romania, who have as main field of activity the non-industrialized and sustainable agriculture. An important objective in the activity of organization is the rescue, conservation and distribution of landrace seeds.

Every year, the NGO publishes a catalogue of landrace seeds, the publication of year 2020 includes a number of 38 species and 106 varieties (among which 30 are represented by tomatoes), and apart from these publications, it also carries out a distribution campaign of landrace seeds called "The Programme of Peasant Seeds - Eco Ruralis". All the 30 tomato landraces stand out by a high diversity of tastes, shapes and colours. It is noteworthy that landraces come from several counties of Romania (Cluj, Buzău, Neamț, etc), but also from other countries such as Spain, France and Siberia. The high diversity of areas of origin offers the farmers the opportunity to pick landraces adjusted to the climate conditions of the areas where they will be cultivated, which is an important thing for obtaining favourable results in the crop.

Other NGOs from Romania with similar preoccupations for the salvage and conservation of landraces are "Fundaţia Civitas pentru Societatea Civilă" with office in Cluj-Napoca, Cluj county and Odorheiu Secuiesc, Harghita county and "Asociația Ecotransilvania" with office in Sighișoara, Mureș county.

According to the specialized literature, we can notice that the highest genetic diversity is encountered in rural areas where the main preoccupation of inhabitants remained the agriculture, where landraces are still cultivated. This practice is based on the principle of conservation in situ and exchanges of seeds.

Among the main dangers which lead to the loss of tomato landraces in Europe and Romania, it is represented by the cultivation of reduced areas, only for personal and especially local consumption, but also the old age of farmers. The global climate changes, the change of habitat and invasive species are other factors which contribute to the loss of landraces. These issues represent a high risk for the loss of tomato landraces in regions of Europe, Romania and the whole world (Figàs et. al., 2019). 
Another important problem which leads to genetic erosion and implicitly the loss of landraces is the preference of farmers for the modern productive assortments, with high uniformity and very nice-looking (Maxim et. al., 2007).

Străjeru et al, in 2009 claim that the family gardens play an important part in the conservation of vegetable landraces, because they maintain the genetic diversity by conservation on farm. Many of these family gardens are cultivated with vegetables, spices and even medicinal plants, on reduced areas, mainly for own consumption.

By the cultivation of landraces in the farms or gardens of origin we can preserve a high diversity of landraces and assortments which offer a continuous basis of genetic resources which contributes to the conservation of genetic reserves for the future generations.

\section{PERSPECTIVES AND SOLUTIONS FOR CONSERVATION OF TOMATO LANDRACES}

In order to apply the landrace conservation techniques, it is important to locate the agricultural areas where they are cultivated, but also the vulnerable areas where the landraces are in danger of extinction.

For the rescue of landraces, we can apply different techniques which involve travels to vulnerable areas for the direct collection of seeds from the small producers in view of rescue.

The direct talks with farmers and local inhabitants, to contribute themselves to the collection of seeds from their areas of activity, is another solution for the salvage of assortments, which comes from the help of NGOs with preoccupations in this field. The collection process of seeds involves also the completion of passport descriptors, which highlight the characteristics of each assortment.

Another efficient solution is the organization of fairs with specific purpose, to collect information about the areas and counties where landraces are cultivated, in order to be able to rescue, preserve and why not, to collect seeds from old and valuable assortments.

The exchanges of seeds between the small farmers from different towns of the country contributes efficiently to the rescue of old assortments, but also to their spreading in the areas with a poor reserve.

In order to facilitate and render efficient the collection, exchanges and rescue of landrace seeds, the financial incentives given to farmers and seed rescuers would render more efficient their salvage process.

By the solutions and techniques described above the landrace seeds can be preserved by in situ and ex-situ conservation.

\section{CONCLUSIONS}

This work has highlighted the main problems encountered for the crop plants and among the most important one is the genetic erosion phenomenon which appeared mainly due to industrialized agriculture, by use of uniform assortments with high yield and uniformity, gradually leading to replacement of landraces.

In the present study we highlight the importance of using landraces both for the agricultural systems because of valuable genes, which confer them resistance to biotic and abiotic stress factors, but also for their organoleptic properties, which represent an advantage for consumers.

In view of conservation of genetic resources, we presented the main well-known methods used for conservation, the in-situ conservation by cultivation of landraces in the areas of origin and the ex-situ conservation, which means their conservation in gene banks.

The principal risks identified, which lead to loss of landraces are represented by cultivation of reduced surfaces, the global climate changes, the change of habitat, invasive species and the use of modern assortments with high yield and high uniformity.

Europe and Romania still have a rich genetic diversity of vegetables, especially in rural areas where the traditional family agriculture is still being practised, which continued to be maintained after the appearance of industrialized agriculture.

In Romania, just like in other countries, the local varieties are subject to the risk of extinction. The greatest danger is the old age of small farmers who cultivate them.

For the rescue of landraces, we can apply different techniques, such as travelling to the area and direct collection of seeds from the small producers, direct talks with farmers and inhabitants of areas in order to directly collect the seeds from them.

Another efficient solution is the organization of fairs with a specific purpose, to collect information about the areas or locations where landraces are cultivated, in order to be able to rescue and preserve them and why not, to collect seeds of the old valuable assortments.

Author Contributions: Conceptualization, C.A., A.M, and R.M.P.; methodology, C.A., A.M.; formal analysis, C.A., A.M, and R.M.P.; investigation, C.A., A.M, and R.M.P.; data curation, C.A. and A.M,; writing-original draft preparation, C.A,; writing-review and editing, C.A, A.M, and R.M.P.; supervision, C.A. and A.M. 
Funding Source: This research did not receive any specific grant from funding agencies in the public, commercial, or not-for-profit sectors.

\section{Conflicts of Interest}

The author declares that she does not have any conflict of interest.

\section{REFERENCES}

1. Bayus, T., and Trygve, B., (2007). Genetic erosion of Ethiopian tetraploid wheat landraces in Eastern Shewa, Central Ethiopia. Genetic Resources and Crop Evolution, 54 (4), 715-726.

2. Bertoldo, J.G., Coimbra, J.L.M., Guidolin, A.F., Braatz de Andrade, L.R., Nodari, R.O. (2014). Agronomic potential of genebank landrace elite accessions for common bean genetic breeding. Sci. agric. (Piracicaba, Braz.), vol.71, n.2:120-125.

3. Chable, V., (2005). Conserving and developing crop biodiversity - biodiversity and local ecological knowledge in France, Edition Cemagref, Cirad, Ifremer, Inr; Iddri, IFB.

4. Ciofu, R., Stan, N., Popescu, V., Chilom, P., Apahidean, S., Horgoș, A., Berar, V., Lauer, K.F., Atanasiu, N., (2004). Tratat de legumicultură, Ed. Ceres, București.

5. Cleveland, D.A., Soleri, D., Smith, S.E., (1994). Do folk crop varieties have a role in sustainable agriculture? Bioscience 44, 740-751.

6. Derpsch, R., Roth, C.H., Sidiras, N., Köpke, U., (1991). Controle de erosão no Paraná, Brasil: Sistema de cobertura do solo, plantio direto e preparo conservacionista do solo. Sonderpublikation der GTZ, No. 245. Rossdorf, Germany, TZ-Verlagsgesellschaft GmbH., 272.

7. EUROSTAT (2020). Crop production in hational humidity. https://appsso.eurostat.ec.europa.eu/nui/submitViewTableAction.do Accesed 07.09.2020

8. FAOSTAT (2019). Statistical Databases. Food and Agriculture Organization. http://www.fao.org/faostat/en/\#data/QC. Accesed 20.08.2020

9. Figàs, M., R., Prohens, J., Diez, J., M., Soler, S., (2019). Recovering and enhancing the local tomatoes of the Vall d'Albaida, an inland district in the region of València (Spain). Establishing the European Network for In Situ Conservation and Sustainable Use of Plant Genetic Resources. Landraces. Issues 4 January.

10. Fowler, C., and Pat, M., (1990) Shattering. Food, Politics, and the Loss of Genetic Diversity, Tucson, Arizona.

11. Institutul Național de Statistică - Producția vegetală la principalele culturi, 2019. https://insse.ro/cms/sites/default/files/field/publicatii/productia vegetala la principalele culturi in anul 2018 0.pdf. Accesed 20.08.2020

12. Izahur, H., Sher, A., K., Sajid, A., Abid, F., Naushad, A., Sardar, A., Shah, M., Ijaz, H., Kamran, A., Haneef, R., (2018). Genetic Diversity among Tomato Accessions based on Agro-Morphological Traits (Kepelbagaian Genetik antara Penerimaan Tomato berdasarkan Ciri Agro Morfologi). Sains Malaysiana. 47(11), 2637-2645.

13. Jarvis, D., I., Myer, L., Klemick, H., Guarino, L., Smale, M., Brown, A.H.D., Sadiki, M., Sthapit, B., and Hodgkin, T., (2000). A Training Guide for in Situ Conservation On-farm, Version 1, International Plant Genetic Resources Institute, Rome, Italy, p. 4.

14. Jarvis, D.J., Brown, A.H.D., Cuong, P.H., Collado-Panduro, L., Latournerie-Moreno, L., Gyawali, S., Tanto, T., Sawadogo, M., Mar, I., Sadiki, M., Thi-Ngoc Hue, N., Arias-Reyes, L., Balma, D., Bajracharya, J., Castillo, F., Rijal, D., Belqadi, L., Rana, R., Saidi, S., Ouedraogo, J., Zangre, R., Rhrib, K., Chavez, J.L., Schoen, D., Sthapit, B., De Santis, P., Fadda, C., and Hodgkin, T., (2008). A global perspective of the richness and evenness of traditional cropvariety diversity maintained by farming communities.

15. Johannes, M., M., E., Lorenzo, M., (2018). Theorien der Lebendsammlung. Pflanzen, Mikroben und Tiere als Biofakte in Genbanken. (Lebenswissenschaften im Dialog 25). Edition: Nicole C. KarafyllisPublisher: Euro. Verlag, Freiburg/München.

16. Kenet, O., T., George, C., Jane, A., Willis, O., (2018). Evaluation of African tomato landraces (Solanum lycopersicom) based on morphological and horticultural traits. Agriculture and Natural Resources 52, 536-542.

17. Krasteva, L., Todorova, T., (2003). The Bulgarian Solanaceae collections. In: Daunay, M.C., L., Maggioni, and E., Lipman, compilers. Solanaceae genetic resources in Europe. Report of two meetings - 21 September 2001, Nijmegen, The Netherlands / 22 May 2003, Skierniewice, Poland. Rome: I PGRI, 2003, p. 15-26.

18. Kulus, D., (2018). Genetic resources and selected conservation methods of tomato. Journal of Applied Botany and Food Quality 91, p. 135-144. 
19. Lammerts van Bueren, E.T., Struik, P.C., Jacobsen, E., (2002). Ecological aspects in organic farming and its consequences for an organic crop ideotype. Netherland Journal of Agricultural Science 50, p. 1-26.

20. Lever, L.A., (2006). A Survey of Landraces on the Shetland Islands. MSc thesis, School of Biosciences, University of Birmingham, Birmingham, UK.

21. Martí, R., Rosello, S., Cebolla-Cornejo, J., (2016). Tomato as a source of carotenoids and polyphenols targeted to cancer prevention. J. Canc. 8, 58. https://www.ncbi.nlm.nih.gov/pmc/articles/PMC4931623/.

22. Maxim, A., Sima, R., Fiţiu, A., Sandor, M., Papp, R., Lucian, C., Hapca, A., (2007). Preliminary results concerning the preservation of genetical diversity of different vegetable varieties at USAMV Cluj-Napoca. Bulletin of the University of Agricultural Science and Veterinary Medicine, Cluj-Napoca, 63/2007, Agriculture, p. 291-296, ISSN 1843-5246.

23. Maxim, A., (2008). Ecologie generală şi aplicată. Editura Risoprint, Cluj-Napoca.

24. Maxim, A., Jidavu, M., Șandor, M., Sima, R., Papp, R., Hapca, A., Lucian, C., (2008). Research regarding the conservation of genetical diversity of lettuce (Lactuca Sativa). Simpozionul "Agricultura modernă-realizări şi perspective" Chișinău, Moldova Horticultură, viticultură, silvicultură și protecția plantelor, 16, 169-174.

25. Maxim, A., Sima, R., Şandor, M., Papp, R., Lucian, C., Hapca, A., Maxim, O. I., Lucaci, A., (2008). Aspects regarding seeds quality from local varieties of vegetables, collected from different areas of Romania. Acta Universitatis Cibiniensis. Seria Ştiinţe Agricole, vol. 1, nr. 1/2008, ISSN 1582-8549.

26. Maxim, A., Străjeru, S., Albu, C., Sandor, M., Mihalescu, L., Pauliuc, E., S., (2020). Conservation of vegetable genetic diversity in Transilvania-Romania. Scientific Reports, 10, 1-11. https://www.nature.com/articles/s41598-020-75413-x.

27. Maxted, N., Ford-Lloyd, B.V., and Hawkes, J.G., (1997). Complementary conservation strategies. In: Maxted, N., Ford-Lloyd, B.V., and Hawkes, J.G. (eds.) Plant genetic conservation: the in situ approach. Chapman \& Hall, London,UK. 20-55.

28. Micheloni, C., (2004). On farm seed production: integrity of organic farming system and biodiversity safeguard. Proceedings of the first world conference on organic seed, Rome July 5-7; FAO Rome.

29. Ministerul Agriculturii și Dezvoltării Rurale din România (MADR). https://www.madr.ro/docs/agricultura/agricultura-ecologica/2020/Dinamica-operatorilor-\%C8\%99i-asuprafe\%C8\%9Belor-\%C3\%AEn-agricultura-ecologic\%C4\%83.pdf. Accesed 20.08.2020

30. Negri, V., Maxted, N., Veteläinen, M., (2009). European Landrace Conservation: an Introduction. European landraces: on farm conservation, management and use. Biodiversity Technical Bulletin no 15. European Cooperative Programme for Plant Genetic Resources. Rome, Italy.

31. Nikolaou, L., and Maxted, N., (2009). Community-based Landrace Conservation: Lentils of Eglouvi, Lefkada. Biodiversity Technical Bulletin no 15. European Cooperative Programme for Plant Genetic Resources. Rome, Italy, 233-232.

32. Recensământul General Agricol 2010 date provizorii (2011) http://www.fao.org/fileadmin/templates/ess/ess test folder/World Census Agriculture/Country info_201 0/Reports/Reports 4/ROM ROU PRE REP 2010.pdf Accesed 20.08.2020

33. Stan, N., Munteanu, N., Stan, T., (2003). Legumicultură - Vol. III, Ed. Ion Ionescu de la Brad, Iași.

34. Sthapit, B.R., Rana, R., Eyzaquirre, P., \& Jarvis, D.I., (2008). The value of plant genetic diversity to resourcepoor farmers in Nepal and Viet Nam. International Journal of Agricultural Sustainability, 6(2): 148-166.

35. Stickland, S., (1998). Heritage vegetables: the gardeners' guide to cultivating diversity. Gaia Books Ltd., London, UK.

36. Străjeru, S., Muraru, D., Constantinovici, D., (2006). Bank of plant resources. Edition Universității, Suceava.

37. Străjeru, S., Ibănescu, M., Constantinovici, D., (2009). Landrace Inventories: Nees and Methodologies. European Cooperative Programme for Plant Genetic Resources. Rome, Italy. Biodiversity Technical Bulletin. no 15. 137142.

38. Străjeru, S., (2018). Catalogul speciilor legumicole. Editura PIM. ISBN 978-606-13-4639-4. https://www.svgenebank.ro/publications ro.asp. Accesed 08.09.2020

39. The Second Report on the State of the world`s Plant Genetic Resource for Food and Agriculture. Commision on Genetic Resources for Food and Agriculture. Food and Agriculture Organization of the Unaited Nation. Rome 2010.

40. Vallverdú - Queralt Anna, A., Medina-Remón, J., Casals-Ribes, Rosa, Lamuela - Rraventes, (2011). Is there any difference between the phenolic content of organic and conventional tomato juice?, Food chemistry, 130: 222227. 
41. Veteläinen, M., Negri, V., Maxted, N., (2009). A European Strategic Approach to Conserving Crop Landraces. Biodiversity Technical Bulletin no 15. European Cooperative Programme for Plant Genetic Resources. Rome, Italy.

42. Villa, I., (2005). Defining and identifying crop landraces. Plant genetics resources: characterisation and utilisation, 373-384.

43. William, C., H., Mohamed, H., M., Oshingi, S., (2016). Eco-geographic Distribution of Tomato (Solanum lycopersicon 1.) Landraces in Tanzania: Implications for Conservation and Sustainable use of Plant Genetic Resources. International Journal of Research in Agriculture and Forestry. Vol. 3, Issue 9, 14-21.

44. Zaharia, H., and Kastler, G., (2003). European Union: Seeds and plants - legislative progress? Citizen Earth, Issue No 6, 6.

45. ${ }^{* * *}$ https://www.ecpgr.cgiar.org/ Accesed 08.09.2020

46. ${ }^{* * *}$ https://ec.europa.eu/info/sites/info/files/food-farming-fisheries/farming/documents/tomatoesproduction en.pdf Accesed 10.10.2020

47. *** https://ourworldindata.org/grapher/tomato-yields Accesed 08.09.2020

48. $* * *$ https://ourworldindata.org/grapher/tomato-yields?time=2018\&country= ROU\&region=Europe Accesed 08.09.2020. 